\title{
BATALKA KRISZTINA
}

\section{ÚJ MÜEGYETEMEK ALAPÍTÁSI KÍSÉRLETEI A 20. SZÁZAD ELSÖ ÉVTIZEDÉBEN - A CSAKNEM MEGNYÍLT TEMESVÁRI MÜEGYETEM*}

\begin{abstract}
A dualizmus korának nagyarányú ipari fejlödése és a Királyi József Müegyetem túlzsúfoltsága miatt szükségessé vált a 20. század fordulóján egy második müegyetem felállitása. A szakemberek, a Királyi József Müegyetem tanárai, illetve a kormány is azt javasolta, hogy ezt az egyetemet Temesváron, a Délvidék ipari központjában hozzák létre. Ehhez mind gazdasági, oktatási és nemzeti szempontokat is figyelembe vettek. A konkrét tervekkel ugyan 1917-re elkészültek, de történelmi okok miatt az intézmény csak 1920 öszén nyilhatott meg, most viszont már román politechnikumként. Temesvár mellett Kassán tervezték a harmadik magyar müszaki egyetem fölállitását, de az elökészületekkel nem jutottak olyan messzire, mint Temesvár esetében.
\end{abstract}

Kulcsszavak: felsőoktatás, műszaki egyetem, Temesvár, politechnikum, Kassa

THE Founding EXPERIMENTS OF NEW TECHNICAL UNIVERSITIES IN THE FIRST DECADE OF THE $20^{\text {TH }}$ CENTURY. THE ALMOST-OPENED TECHNICAL UNIVERSITY IN TIMISOARA. Due to the need for industrial development in the era of dualism and the overcrowding of the Royal Joseph Technical University, the founding of the second Hungarian technical university became one of the most pressing problems of higher education at the turn of the $20^{\text {th }}$ century. The professional public, the Royal Joseph Technical University and the government both imagined the establishment of the institution in Timisoara which was the industrial-commercial center of Southern Land. They took into consideration economic, educational and national aspects as well.

The concrete plans were completed by 1917, but due to historical events, the institution was founded only in the autumn of 1920 as a Romanian Politechnic. In addition to Timisoara, Kosice was the planned seat of the third Hungarian technical university, but the preparations were not as far away as in Timisoara.

Keywords: higher uducation, technical university, Timisoara, politechnic, Košice

A felsőoktatás helyzetére az első világháború előtti évtizedekben az átalakulás volt jellemző, mivel nem állt rendelkezésre az ország és a lakosság méretének megfelelő számú és minőségű (vidéki) felsőoktatási intézmény (ennek megfelelően a budapestiek túlzsúfoltak voltak). A fejlesztésre vonatkozó közgondolkodás és kormányzati tervek egyik jelentős eleme a második magyar műegyetem létrehozása volt. ${ }^{1} \mathrm{~A}$ kérdés azért is

* Az új műegyetemek létesítésének kérdéskörét elsőként Szögi László foglalta össze: SzöGI László, „A temesvári és kassai műegyetem létesítésének tervei 1918 elött”, in Tanulmányok a magyar felsöoktatás XIX-XX. századi történetéből, szerk. KIss József Mihály, Fejezetek az Eötvös Loránd Tudományegyetem történetéből, 14, 105-122 (Budapest: ELTE Levéltára, 1991). Jelen tanulmány a temesvári egyetemalapítási kísérletet fejti ki részletesebben, illetve ehhez tár fel újabb adalékokat.

${ }^{1}$ Az 1896-ban rendezett első magyar technikuskongresszus már kifejezte az alapítás fontosságát és szükségességét. Vö. SzöGI, „A temesvári...”, 107. 
válhatott a századforduló éveinek egyik legsürgetőbb felsőoktatási problémájává, mert a dualizmus kori iparfejlődés, vasútépítés, vízszabályozás egyre növekvő számú műszaki szakembert, az pedig egyre több hallgatót igényelt a szakirányú felsőoktatásba. Ehhez képest csak két műszaki felsőoktatási intézmény működött az országban (a Műegyetem mellett a Bányászati és Erdészeti Főiskola Selmecbányán), miközben a Monarchia nyugati részén hét, köztük Bécsben, Prágában, Brünnben, Grazban. Bár az 1890-es évek végén a Mủegyetem hallgatói létszámával a harmadik helyen állt Európában Berlin és München után, ezzel együtt, amíg Németországban 10000 lakosra kettő, Ausztriában másfél, nálunk kevesebb mint egy műegyetemista jutott. A következő évtizedben a létszám megduplázódott, míg az utolsó békeévre már ismét majdnem megduplázódott. ${ }^{2}$ A gyorsan növekvő hallgatószám miatt azonban az egyetem már akkor túlzsúfolttá vált, amikor 1909-ben átköltözött a Múzeum körútról a lágymányosi, mai történeti campusára. Ráadásul - ahogy arra a szakemberek rámutattak - nemcsak fizikai, hanem szellemi értelemben vett zsúfoltság is jelentkezett, azaz felmerült a tömegoktatás versus minőségi oktatás problémaköre. A tűzoltásszerü megoldások (párhuzamos előadások és gyakorlatok tartása, a tanszemélyzet számának növelése, rajztermi helyiségek bővítése) mellett már ekkor felvetődött a felvételi korlátozás (numerus clausus) bevezetése is. A döntést 1913-ban azzal halasztották el, hogy egyrészt éppen egy új szakosztályt készül felállítani az intézmény (ez volt az 1914 őszétől működését megkezdő közgazdasági osztály), másrészt pedig az intézkedés éppen a mérnöki pályára készülőket riasztaná el a szakemberhiányos területről.

Amíg a tudományegyetemek ügyében Pozsony és Debrecen mellett gyorsan kormányzati döntés született, addig a második műegyetem ügyében a szakmai közvéleményben két álláspont alakult ki. Az egyik szerint a meglévő selmecbányai intézmény teljes technikai főiskolává történő fejlesztése (vagy áthelyezése) szükséges, míg a másik álláspont képviselői a Délvidék legiparosodottabb városa, közlekedési központja, Temesvár mellett érveltek. A kolozsvári egyetemen létrehozandó műszaki fakultás terve is felmerült (itt volt még természettudományi képzés az országban), ám azt a teljes és önálló műegyetem igénye miatt hamar elvetették. ${ }^{3}$

2 A műegyetemi hallgatók számának változása 1891-1913 között a II. félévi beiratkozások átlaga alapján: 1891-1895: 729 fó, 1896-1900: 1256 fö, 1901-1905: 1442 fö, 1906-1910: 1329 fö, 1909/10. II.: 1520 fö, 1910/11. II.: 1687 fö, 1911/12. II.: 1885 fö, 1912/13. II.: 2131 fö, 1913/14. II.: 2461 fö. Forrás: VIcZián János, Diákélet és diákegyesületek a budapesti egyetemeken 1914-1919, Felsőoktatástörténeti kiadványok. Új sorozat 2 (Budapest: ELTE Levéltára, 2002), 17, 19-20.

${ }^{3}$ A kérdésben Cholnoky Jenő professzor képviselte elsősorban a kolozsvári érdekeket, azonban a Magyar Mérnök és Építész Egyletben tartott 1911-es vitán a műszaki szakemberek egyértelműen úgy vélekedtek: nem tartják műegyetemre valónak a tudományegyetemi tanárokat, mivel előbbi oktatás más gondolkodásmódot, képzettséget követel, valamint lehetőleg olyan városban alapítsanak új müegyetemet, ahol még nincs egyetem, viszont ipar igen, „mert ahol az ipar nincs meg, a müegyetem nem fog boldogulni. [...] A müegyetemet ne egyesitsük az egyetemmel; ebböl sohasem lenne többé valódi müegyetem, márpedig nekünk csak az kell. Ha már csinálnak valamit, csináljanak egész müegyetemet, önállóan és függetlenül minden más felsöiskolától." Magyar Mérnök és Épitész Egylet Közlönye 51 (1911): 661-662. 
Maga Temesvár már 1907-ben benyújtotta a második mủegyetem helyszínének elnyerését kérő feliratát Apponyi Albert vallás- és közoktatásügyi miniszternek, az ország többi városát megelőzve (igaz, eredetileg az ország harmadik tudományegyetemének székhelyét szerették volna magukénak). ${ }^{4}$ Ráadásul ettől kezdve céltudatosan végezték az előkészítés munkáját, például a város 1905-1906-ban zajló felmérését már a jövőbeli városfejlesztési tervekre tekintettel készítették el..$^{5}$ A délvidéki város kérését a Magyar Mérnök és Építész Egylet is támogatta, amelynek temesvári osztálya 1910. január 23-án tartotta alakuló közgyülését. Kájlinger Mihály elnök a magyar mérnökképzés fejlesztéséről tartott beszédében a második müegyetem „égetö szüusségét és a kérdésnek állandó felszinen tartását" hangoztatta, hozzátéve, hogy Temesvár helyzeténél és fejlettségénél fogva a "legalkalmasabb központ arra, hogy az uj mérnökképzö az igényeknek megfelelöen elhelyeztessék". ${ }^{6}$

Miután 1911-ben Zichy János kultuszminiszter is támogató értelemben nyilatkozott, sőt az évi költségvetésben 50 ezer korona hitelt engedélyezett az új egyetemek és kifejezetten a második műegyetem előkészítő munkáira, a város év végén bizottságot hívott életre az egyetemalapítás előkészítésére. A saját költségvetéssel rendelkező testület véleményét minden érdemleges városi határozat elött ki kellett kérni. A bizottság elnöke hivatalból a polgármester, tagjai pedig a temesvári fojjegyzon, a föügyész, a fómérnök és a kulturális ügyeket előadó tanácsnok voltak, valamint választás útján 24 fö törvényhatósági bizottsági tag került be. ${ }^{7}$ A bizottságban való közreműködésre kérték fel továbbá Temes, Torontál és Krassó-Szörény vármegyék, Pancsova és Versec városok, a temesvári Kereskedelmi és Iparkamara, a temesvári Lloyd Társulat, a Mérnök és Építész

${ }^{4}$ Temesvár első felsőoktatási intézménye az 1806-ban megnyitott püspöki szeminárium volt, a Bölcsészeti Líceum pedig 1841-ben nyílt meg, néhány év múlva jogi fakultással kibővülve. Szögi László kutatásaiból kiderül: a líceum már akkor létező, hatalmas igényt elégített ki mind a bölcsész-, mind a jogi felsőoktatást tekintve. Vö. Szögr László, A temesvári felsöoktatás intézményeinek hallgatói 1804 1852, Felsőoktatás-történeti kiadványok. Új sorozat 17 (Budapest: ELTE Levéltára, 2018), 9-24. A természettudományos és műszaki jellegű alap- és középfokú, valamint szakoktatás fejlődésének ügyét a város már régóta napirenden tartotta: az első állami főreáliskolát 1870-ben alapították majdnem 20 éves küzdelmet követően, 1879-ben pedig megnyílt az állami fa- és fémipari szakiskola. Az 1884. évi XVII. törvény, azaz az új ipartörvény életbelépését követően pedig négy iparostanonc-iskola is alakult. Vö. BellaI József, „Temesvár közoktatásügye”, in Magyarország vármegyéi és városai, szerk. Borovszky Samu (Budapest: Országos Monografiai Társaság, 1914), 184-203.

5 A város felmérése Szesztay László műegyetemi magántanár közreműködésével történt meg, amelynek során minden olyan építményt feltüntettek, amelyek a városban megtalálhatók voltak, valamint megkezdték a térkép bővítését is, elsősorban városfejlesztési célzattal. Lásd Városi Közlöny 1 (1906), 1906. január 15.

${ }^{6}$ Városi Közlöny 2-3 (1910), 1910. február 15., 147-148.

A választott tagok névsora: Baader Henrik, Csasznek József, Cseresnyés Jenő, Demkó Jenő, dr. Fáy Ignác, Klein Jakab, Klein Jenő, Krémer József, dr. Laky Mátyás, dr. Láng Béla, Láng Dávid, Nemes József, Pacha István, dr. Pekáry Géza, Pelikán Lipót, Petheő János, dr. Steiner Adolf, Steiner Ferenc, Steiner Károly, Szabolcska Mihály, dr. Sztura Szilárd, Tedeschi János, dr. Vértes Adolf. és dr. Weisz Ferenc. Városi Közlöny 11-12 (1911), 1911. november 15., 423. 
Egylet temesvári osztálya, a Temes megyei gazdasági egyesület, valamint a Délvidéki Földmívelők Gazdasági Egyesülete képviselőit. ${ }^{8}$ Az előkészítő munkálatok első lépése a szükséges építkezések felmérése és az ezzel kapcsolatos javaslatok készítése volt, mivel úgy gondolták: „[...] elöreláthatólag az elhelyezésröl való gondoskodás volna a város támogatásának az a módja, mely a müegyetem megvalósitását legbiztosabban elömozditaná". A testület ezt követően 1912 őszén bízta meg Zelovich Kornél műegyetemi professzort a kérdéskör áttekintésére és feldolgozására. A kétéves munkával készített átfogó emlékirat éppen egy nappal a Ferenc Ferdinánd elleni merénylet után készült el. ${ }^{10}$

Az emlékirat első része a második műegyetem létrehozásának szükségessége melletti érveket sorakoztatta fel a technikai fejlődés jelentőségétől kezdve a technikai föiskoláknak a (tudomány)egyetemekhez és a lakosságszámhoz viszonyított arányán át a műegyetemi hallgatók létszámadatainak ismertetéséig bezárólag. A szerző a felsorolt adatok alapján arra a következtetésre jutott, hogy az ország gazdaságának érdekei, a budapesti Műegyetem tehermentesítése és a technikusképzés eredményessége a második müegyetem létrehozását „parancsolóan sürgetik”. A dokumentum következő fejezetében Temesvárt jelölte meg legalkalmasabb székhelyként. Ennek bizonyítására áttekintette a német technikai felsőoktatási intézmények elhelyezését, amelyek kivétel nélkül fóvárosban, valamint ipari és kereskedelmi gócpontokban voltak megtalálhatók. A magyar oktatásügy térképét elemezve a Délvidék egyetemnélküliségét hangsúlyozta, amelynek ipari-kereskedelmi központja Temesvár. Az egyébként vasútépítő mérnök Zelovich az egyik legfőbb érvként a város (nemcsak vasúti, de közúti és vízi) közlekedési, és így kereskedelmi csomópont jellegét támasztotta alá pontos adatokkal. Az ipari jelentőség

${ }^{8}$ A felkért testületek az alábbi küldötteket nevezték meg: Ferenczy Sándor alispán, báró Ambrózy Gyula nagybirtokos és dr. Szentkláray Jenő kanonok Temes megye részéről; dr. Dellimanics Lajos főispán, Jankó Ágoston alispán, dr. Vinczehidy Ernő fójegyző, valamint Babies József udvari tanácsos, Papp Géza nagybirtokos, országgyủlési képviselő, báró Tallián Béla országgyűlési képviselő Torontál megye részéről; dr. Medve Zoltán főispán, Issekutz Aurél alispán, Huszár Károly földbirtokos, országgyủlési képviselő, Nikolits Dániel bizottsági tag, Fränkl Nándor ügyvéd, bizottsági tag, Boross János nagyprépost, pápai prelátus Krassó-Szörény megye részéről; dr. Rezucha István királyi tanácsos, polgármester, Szalay László városi fömérnök, Heegn Reinhold magánmérnök Versec törvényhatósági jogú város részéről; dr. Radda Ignác polgármester Pancsova törvényhatósági jogú város részéről; Vest Ede lovag, udvari tanácsos, Lendvai Jenő titkár, Kohn Sándor kereskedelmi tanácsos a Kereskedelmi és Iparkamara részéről; nagypéli Sternthal Salamon első igazgató, Sigmund János másodigazgató, Neubauer Vilmos titkár a temesvári Lloyd Társulat részéről; Wallandt Ernő nyugalmazott miniszteri tanácsos, Podhoránszky Géza királyi műszaki fötanácsos, Paulay Gyula Béga-szabályozási társulati mérnök a Mérnök- és Építész Egylet temesvári osztálya részéről; Csíki Gyula nagybirtokos, elnök, dr. Fülöp Béla udvari tanácsos, Jeszenszky Béla nagybirtokos, Vargics Imre nagybirtokos, Bászel Elek titkár a Temes megyei gazdasági egyesület részéről; valamint Blaskovits Ferenc apátkanonok, elnökhelyettes, dr. Frecot Menyhért ügyvéd, elnökhelyettes, dr. Muth Gáspár választmányi tag, Dőld István titkár a Délvidéki Földmívelők Gazdasági Egyesülete részéről. Városi Közlöny 5 (1912), 1912. május 15., 213-214.

9 Városi Közlöny 1 (1912), 1912. január 15., 59.

10 Zelovich Kornél, Emlékirat a Temesvárott felállitandó Müegyetem tárgyában (Temesvár: Csendes, 1917). Az emlékirat megtalálható a BME OMIKK könyvtári állományában a 404.021. raktári számon. 
bizonyítására többek között azt az 1911-es adatot ismertette, amely szerint 60 kisebbnagyobb gyár müködött a városban, ezek közül csak a legnagyobbak mintegy 3500 fót foglalkoztattak (pl. a dohánygyár, a Turul Cipőgyár vagy a gyufagyár). Végül az emlékirat hosszasan ismertette a Temesváron létrehozandó második műegyetem szervezetét, a tervezett hallgatói és oktatói létszámot, valamint a szükséges építési munkákat és költségeket. A szervezettel kapcsolatban - külföldi példákat elemezve - Zelovich nem látott okot arra, hogy a budapesti Mủegyetemétől eltérő legyen a szakosztályi (kari) tagolódás, azaz építészeti, mérnöki, gépészmérnöki, vegyészmérnöki és az általános tudományokat (matematika, természettudományok) magába foglaló egyetemes szakosztályokban gondolkodott (hozzátéve, hogy a budapesti Mủegyetemen éppen akkor megalapított közgazdasági osztály létrehozása a második műegyetemen is szükséges lesz a jövőben). A teljes müegyetemmé válás a budapesti intézmény tehermentesítésének is fontos érve volt, hiszen - ahogy az emlékirat szerzője kimutatta - az 1912/13. tanévig eltelt legutóbbi 30 évben az építészeti, illetve a vegyészmérnöki szakosztályokban hétszeres, a gépészmérnökiben hatszoros, a mérnökiben pedig háromszoros lett a hallgatói létszám. Ugyanakkor Zelovich nem zárta ki azt sem, hogy egyes speciális tudományágak ne kerülhessenek hangsúlyosabb helyzetbe, így például Temesváron a városépítő tudományok intenzívebb művelését javasolta, tekintve, hogy a településen egyébként is kiemelkedő városépítészeti és városi közműalkotások létesültek (pl. vízi erőmű, csatornázás, villanytelep, légszeszgyár, villamosvasút).

Érdekes oktatástörténeti adalék, hogy a tervezett hallgatói létszám megadásakor egy olyan friss bécsi tanulmányra hivatkozott, amely az oktatás eredményessége szempontjából vizsgálta és állapította meg az optimális hallgatói létszámot a műegyetemeken. ${ }^{11}$ Ezt, illetve a budapesti zsúfoltság adatait is figyelembe véve 2000 fóben maximálta a temesvári hallgatói létszámot azzal, hogy egyelőre elegendő a felére tervezni, „de oly módon, hogy az épületeknek 2000 hallgató befogadására való fokozatos kibövithetése annak idején akadályokba ne ütközzék". ${ }^{12}$

A fenntartási kiadások tervezésekor egyrészt mind az egy fö hallgatóra jutó, mind pedig a rendes tanárok számához viszonyító összegeket áttekintette (Budapesten és a német egyetemeken is). Utóbbi metódust pontosabbnak minősítve, a tervezett tantárgyak előadásához szükséges 32 egyetemi tanárral és a hallgatók számához igazodó segédtanszemélyzettel számolva kb. 800000 koronában állapította meg az éves kiadás összegét (ebben már a dologi költségekkel is számolva). Az emlékirat az épületek tervezésekor fóépülettel (benne előadótermek, rajztermek, tanári szobák, hivatali helyiségek, könyvtár), kémiai és elektrotechnikai épülettel, valamint egyéb laboratóriumokkal és étkezőhelyiségekkel számolt. Mindehhez Zelovich azt a $80000 \mathrm{~m}^{2}$ alapterületü, a város belső részén található telket, amelyet Temesvár felajánlott, elegendőnek és alkalmas-

${ }^{11}$ Hans von JüPtner, Zur Ausgestaltung unserer technischen Hochschulen (Wien: Fromme, 1912).

12 Zelovich, Emlékirat..., 23. 
nak ítélte meg. ${ }^{13} \mathrm{Az}$ építési költségek esetében ismertette a nemrég elkészült budapesti műegyetemi épületek 13 millió koronás összegét, amelyet további 2,5 millió koronával növelt meg a tudományos felszerelések beszerzése. A temesvári beruházást ennél valamivel kevesebbre, mintegy kilencmillió koronára becsülte (a város által felajánlott telek költsége nélkül).

Az első világháború kitörését követően az új mủegyetem(ek) létesítése már katonai szempontból is fontossá vált (károk, veszteségek, gazdasági erő fokozása stb.). A temesvári testület mellett 1916-ban a Királyi József Mủegyetemen is bizottságot hívtak életre, elnöke Kürschák József rektor, tagjai Hermann Miksa, Kovács-Sebestyén Aladár, Pecz Samu, Rados Gusztáv, Schimanek Emil, Szarvasy Imre, Zelovich Kornél, Zielinski Szilárd professzorok voltak. A bizottság „a háború okozta bajok orvoslását célzó nemzeti tevékenység sorába"állítandó országos közérdeknek minősítette az egyetem létrehozását, és annak nyomatékosításáról sem feledkeztek meg, hogy az ország gazdasági világversenyben való teljesítőképességét a mérnökök munkája teheti hatékonyabbá: „A második müegyetem felállitását a békés idök szülte természetes fejlödés megkövetelte; szükségének érzetét a közben jött háború kiélezi és megvalósitását immár elodázhatatlanná teszi. ${ }^{14}$

Ezzel egybecsengően nyilatkozott Temesvár is:

„Azért is aktuálissá lett ez a kérdés, mert egyfelől a háborúban elpusztult, vagy a háború alatt bekövetkezett általános pangás folytán elő nem állított javak pótlása, másfelől pedig a háború megszűnte után minden vonalon szükségképpen bekövetkezendő többtermelés, a technikai ágazatok mindenikében jelentékeny munkaszaporulatot fog maga után vonni, ami a technikai pályákra való törekvést természetszerủen élénken emelni fogja. Ne találja ez a közeli jövőben bekövetkezendő állapot Temesvár városát készületlenül. A temesvári műegyetem kérdésével a háború előtt behatóan foglalkoztunk; az előkészítést a háború már igen előre haladott stádiumban találta. [...] A városi tanács tehát újból felveszi a temesvári műegyetem előkészítésének a háború folytán megszakadt fonalát és azon lesz, hogy az ügy állásáról a tekintetes törvényhatósági bizottságnak minél előbb konkrétebb alakban tehessen jelentést." ${ }^{”}$ „A város közönsége teljes tudatában lévén annak, hogy egyfelől a technikai munka nagy nemzetgazdasági jelentősége, mely a háború után szükségképpen beálló többtermelés folytán lényegesen fokozódni fog, másfelől a mindinkább érezhető mérnökhiány és egyetlen műegye-

${ }^{13}$ A Gyárváros és Erzsébetváros között, a Béga-csatorna közelében található telek nagysága biztosította volna azt a $16 \mathrm{~m}^{2} /$ hallgató alapterületet is, amely Jüptner professzor tanulmányában olvasható. Öszszehasonlításul: a Budapesti Műszaki és Gazdaságtudományi Egyetem esetében a létesítmények összes területét és a hallgatói létszámot alapul véve ez az érték 2018-ban kb. $15 \mathrm{~m}^{2} /$ fö. Vö. Tények és adatok a Müegyetemröl, 2019, https://www.bme.hu/sites/default/files/csatolmanyok/tenyek_es_adatok_2019. pdf, 6. és 23., hozzáférés: 2019. 06. 01.

14 Budapesti Műszaki és Gazdaságtudományi Egyetem Levéltára (a továbbiakban: BMEL) 3/a. 5. d., az Egyetemi Tanács 1917. március 30-i ülésének 134. napirendi pontja. Az ülésen bemutatták a bizottság véleményes jelentését (a jelentés a jegyzőkönyv mellékleteként fennmaradt).

15 Városi Közlöny 5-6 (1916), 1916. május 15., 193. 
temünk túlzsúfoltsága a második magyar műegyetemnek a békekötés után való mielőbbi létesítését elkerülhetetlenül szükségessé teszi, [...] elhatározta, hogy [...] a nm. m. kir. vallás- és közoktatásügyi minister Úrhoz feliratot intéz, kérve, hogy a temesvári műegyetem program úttervének egybeállitása iránt már most intézkedni méltóztassék, hogy a békekötés után ezen nagyhorderejü közgazdasági és kulturális intézmény megvalósítására fennakadás nélküli áttérni lehessen.”16

Eközben a müegyetemi bizottság összeült, és - a Zelovich-féle emlékiratot is alapul véve - munkája során elsőként kiszámolta a várható mérnökszükségletet: 5000 lakosonként 1 fó müegyetemi hallgatóra és a gazdasági élet remélt alakulása esetére becsülve, a várható összhallgatóság számát 4200 főben adták meg. A diákszám növekedésének addigi tendenciáját alapul véve és a kellő számú hallgatót befogadó müegyetemeket feltételezve úgy számolták, hogy 11-12 év alatt érnék el ezt a számot. Mindehhez a második müegyetemet kb. 2000 fósre tervezték. Az oktatással kapcsolatban alapvetően leszögezték, hogy az összes budapesti müegyetemi szakosztály (kar) létrehozása és az azokkal azonos tanulmányi és vizsgarend biztosítása szükséges (ahogyan az emlékirat is tartalmazta).

A Temesvár melletti érvek sokasága között szerepelt az oktatás szempontjából fontos helyek közelsége (Resicabánya, Vaskapu, Béga-csatorna, Temesvár gyárai és ipartelepei), valamint ezzel összefüggésben az is, hogy a közeli bányavidékre való tekintettel „kivánatosnak, söt szükségesnek tartjuk, hogy a temesvári müegyetem programjába a bányászat és a kohászat szintén felvétessék".

A Délvidéknek ekkor már csak papképző felsőoktatási intézménye volt, „pedig ha van országrész, ahol a magyar szellemi és gazdasági szupremácia érdekében a magasabb nemzeti müveltség beolvasztó erejére szükség van, úgy ez a soknyelvü Délvidék bizonyára $a z ”$. A nemzeti törekvések biztosításával párhuzamosan azt is elismerték, hogy az osztrák tőkével az országba, a hazai iparvállalkozásokba beszivárgó „idegen technikusok” eltávolítása szintén évtizedes törekvés a mérnöktársadalom részéről.

További érv volt, hogy a statisztikák szerint a Müegyetemre a Délvidékről jöttek legnagyobb arányban a hallgatók, így egy temesvári egyetemalapítás automatikusan tehermentesítést vont volna maga után (a délvidéki diákok számaránya az 1907/081913/14. tanévekben átlagosan 23,5\%-ot tett ki, átlagosan 14-15\%-os növekedéssel tanévenként, amely átlag másfélszeres növekedést jelentett az ország többi részéből érkező hallgatókéhoz képest). ${ }^{17}$

A majdani diákság érdekeit is tekintve további jelentős előnyként merült fel, hogy Temesvár közlekedési gócpont volt, valamint virágzó kereskedelmi, ipari, gazdasági és

16 Városi Közlöny 7-9 (1916), 1916. július 15., 212-213. Az említett emlékiratot 1916. július 11-én küldték meg a kultusztárcához.

${ }^{17}$ Ennek magyarázata lehet, hogy a nyugati-délnyugati országrészből az osztrák felsőoktatási intézmények vonzása nagyobb volt, másrészt Temesvár körzetében jellemzően megtalálhatók voltak azok a feltételek és igények, „amelyek a mérnöki életpályára irányítják a figyelmet”. 
társadalmi életet biztosított, azaz minden szempontból alkalmasnak és vonzónak bizonyulhatott az ifjúság számára. Ráadásul a városi szociális intézmények és a közösség is késznek mutatkozott a rászoruló egyetemi hallgatóság segítésére, azzal, hogy a diákok akár már tanulmányaik mellett munkával egészíthetik ki jövedelmüket a prosperáló iparközpontban.

Szintén fontos szempont volt a balkáni piac közelsége, amelynek gazdasági és munkaerőigényei a végzés utáni elhelyezkedést könnyűvé tehették, a leendő temesvári müegyetem pedig egyben a bolgár és török diákok továbbtanulását is biztosíthatta volna.

Az egyetemlétesítés financiális oldalát tekintve a müegyetemi bizottság szintén az évtizeddel korábbi lágymányosi campus építési költségeit vette alapul. Ám a temesvári beruházás költségeinek biztosítását a háborús viszonyok megnehezítették, az összeget pedig a gyorsan növekvő infláció miatt szinte még megbecsülni sem lehetett. Az építkezést végül 10 millió koronára, az időközben bekövetkezett drágulás mértékét is beszámítva 15-16 millió koronára becsülték azzal, hogy az új tudományos felszerelésekre és oktatási berendezésekre további 3,5-4 millió korona, az állandó személyi és dologi kiadásokra pedig 1,2 millió korona szükséges. Mindezeket a becsléseket 1000 fó hallgatóra számítva is elvégezték, amely eszerint csak alig 20\%-os megtakarítással járna.

Jelentésüket a Műegyetem tanácsa 1917 tavaszán sürgősséggel tárgyalta és terjesztette fel a kultusztárcának, ekkor ugyanis már a háború után visszaözönlő hallgatóság várható létszáma és az ebből eredő problémák kerültek napirendre az intézményben. Az 1917/18. tanévet megnyitó rektori beszéd fö üzenete is ez volt, azaz mindenképpen szükségesnek találták a második műegyetem mielőbbi megnyitását „legalább ideiglenes helyiségben, a legszükségesebbre szoritkozó felszereléssel". ${ }^{18}$ A mérnöktársadalom továbbra is kiemelten foglalkozott a kérdéssel: 1916 tavaszán az egyletben szintén bizottság ala-

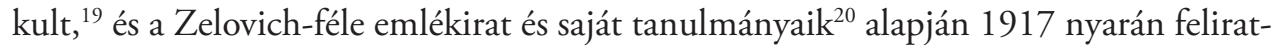
tervet készítettek a második műegyetem mielőbbi létrehozása érdekében. ${ }^{21}$

A három irányból is érkező megkereséseket követően végül Geml József temesvári polgármester kérésére dr. Glattfelder Gyula csanádi püspök kezdeményezte gróf Apponyi Albert kultuszminiszternél, hogy a második műegyetem ideiglenes elhelyezése kérdésében értekezletet hívjon össze. Erre 1917. november 23-án került sor a miniszter, a püspök, Kürschák József műegyetemi rektor, Kájlinger Mihály, a Mérnök és Építész Egylet elnöke, Nagy János államtitkár, Mészáros Károly osztálytanácsos, valamint a temesvári polgármester, továbbá Baader Henrik, Hoitsy Gedeon és Steiner Ferenc te-

${ }^{18}$ Elnöki megnyitó beszéd. Felolvasta: dr. Kürschák József rector magnificus. A magyar Királyi József Müegyetem 1917/18. tanévének megnyitásakor 1917. szeptember hó 23-án tartott beszéd (Budapest: Pesti Lloyd Társulat, 1917), 5-30.

${ }^{19}$ A testület tagjai Hoitsy Gedeon, Cseresnyés Jenő, Szily Pongrác, Kovács Ákos, Szilárd Emil, Székely László, Havalda Endre és Steiner Károly voltak. Magyar Mérnök és Épitész Egylet Közlönye 17 (1917): 171.

${ }^{20}$ Becsey Antal, „A mi nagy problémáink”, Magyar Mérnök és Épitész Egylet Közlönye 20 (1917): 191-194.

${ }^{21}$ A feliratot Becsey Antal készítette, az egylet választmánya 1917. július 13-án fogadta el, szövegét közli a Magyar Mérnök és Épitész Egylet Közlönye 29 (1917): 270-272. 
mesvári bizottsági tagok és Szilárd Emil főmérnök részvételével. A polgármester jelzése szerint a város készen állt arra, hogy a temesvári müegyetem első és második évfolyama egy év múlva, azaz az 1918/19. tanév elején megnyitható legyen. Emellett a temesvári császári és királyi pályaudvar parancsnoksága 1917 decemberében 80000 korona névértékü, „Hess Rezső gyalogsági tábornok alapitvány” néven kezelendő hadikölcsönkötvényt ajánlott fel a városnak azzal, hogy az éves kamatjövedelmet egyelőre a világháborúban részt vett temesvári illetőségủ katonák vagy hozzátartozóik segélyezésére fordítsák, később azonban a temesvári műegyetem arra érdemes hallgatói (mégpedig elsősorban a katona diákok vagy a katonák hozzátartozói) számára éves tanulmányi ösztöndíjak elnyerésére fordítsák. Egyéni kezdeményezések is akadtak: Joanovich Sándor temesi főispán ugyanerre a célra összesen 10000 koronás adományt ajánlott fel tíz éven keresztül ezerkoronánként fizetve. ${ }^{22}$

A kultuszminiszter a kérdésnek a helyszínen történő tanulmányozására újabb bizottságot jelölt ki, amelynek tagjai Tóth Lajos és Kertész K. Róbert miniszteri tanácsosok (utóbbi műegyetemi oktató és a háború utáni technikai felsőoktatásról publikáló szakember), továbbá a budapesti Mủegyetem három professzora (Kürschák József rektor, valamint Tangl Károly és Nagy Virgil) voltak. ${ }^{23}$ A helyszíni szemlére 1918 januárjában került sor. ${ }^{24} \mathrm{~A}$ városháza tanácstermében tartott ülésen Szilárd Emil városi fömérnök mutatta be a temesvári müegyetem ideiglenes elhelyezésére kiszemelt középületek terveit, és ismertette, hogy a város készségesen vállalja az épületek átalakításának munkáját, így valóban lehetőség nyílik arra, hogy az intézményben ősszel megkezdődhetnek az előadások. ${ }^{25}$ Ezután a küldöttek a legalkalmasabbnak látszó épületeket tekintették meg, egyúttal a temesvári középiskolák fizikai, kémiai és természetrajzi szertárait, valamint a műszaki üzemeket is meglátogatták, felmérve, hogy azok mennyiben járulhatnának hozzá a műegyetem ideiglenes felszereléséhez. ${ }^{26}$ Nagy Virgil építészprofesszor 1918 áprilisára kidolgozta az elhelyezésre vonatkozó tanulmányát, amelyben átmeneti, ideiglenes elhelyezést javasolt a hosszabb időt igénybe vevő építkezés helyett azzal, hogy maga az oktatás csak 1919 szeptemberében kezdődhet meg. ${ }^{27}$

22 Városi Közlöny 12 (1917), 1917. december 15., 277.

${ }^{23}$ Kertész K. Róbert, „A felsőbb technikai oktatás a háború után”, Magyar Mérnök és Épitész Egylet Közlönye 50 (1917): 437-446.

${ }^{24}$ Érdekesség, hogy 1918 januárjában ünnepelte meg a város a török hódoltság alól történő fölszabadulásának, illetve az első városi magisztrátus beiktatásának 900 éves fordulóját is. Ez ugyan 1916-ra esett volna, azonban a háború miatt akkor elmaradt. Az eredeti programtervben már szerepelt a műegyetem alapkövének letétele is, azonban még két évvel később is csupán hálaadó istentisztelettel és díszközgyưléssel örökíthették meg a jeles történelmi események emlékét. Budapesti Hirlap 18 (1918), 1918. január 20.

25 Szeged és Vidéke 23 (1918), 1918. január 29.

${ }^{26}$ Délmagyarország 24 (1918), 1918. január 30.

${ }^{27} \mathrm{Ez}$ a temesvári József-laktanya épülete volt. 
Minderről terjedelmes és moralizálástól sem mentes cikkben számolt be Szeged város lapja:

„A napokban érkezett híre annak, hogy a kormány teljesíti Temesvár régi, jogos kívánságát és az új műegyetemet ott fogja fölállítani. Egy szakbizottság már járt is Temesváron a kormány részéről, hogy a műegyetem részére alkalmas helyet szemeljen ki. Körülbelül bizonyos már, hogy a főiskolát Temesvár kapja. Alighogy ez nyilvánosságra került, azonnal megindult két másik magyar város, Arad és Szabadka akciója és azon vannak, hogy a műegyetemet elhalásszák Temesvár elől. A siker minden reménye nélkül mennek a versengésbe, $s$ ezt jól tudják maguk is, de azért mindent elkövetnek, hogy az ügyet legalább megnehezítsék s ahelyett, hogy új intézmények fölállításán és kikilincselésén törnék a fejüket, mások ötleteibe, más városok igényeibe kapaszkodnak. A versengés mindig egészséges és helyes, de a konkurrálásnak ez a módja szomorúan jellemző tünete a magyar városok mások tervei után kapkodó ötletszegénységének. Valamely intézmény fölállítására irányuló mozgalom a magyar városokban csak ritkán indul ki annak a meggondolásából, hogy az illető város fekvése, kultúrája, kereskedelmi és gazdasági élete és sajátságai milyen intézményeket kívánnak. Az ilyen mozgalom rendszerint úgy indul meg, hogy a kormány például Kurdcsibrákon törökmézkészítő előkészítő tanfolyamot állít föl. Erre Aradon, Békéscsabán, Zentán, Baján, Szabadkán és még tíz városban megindul az indítványok és interpellációk, bizottsági ülések özöne, valamennyien törökmézkészítő előkészítő tanfolyamot kérnek, követelnek, sürgetnek a kormánytól és mostohaságról beszélnek, ha az előkészítő tanfolyam Alsókubinba kerül, amely nem is reflektált e nagyjelentőségű intézményre. Egymást akadályozni, egymás lábát elkapni és egymás terveit minden ok nélkül meghiúsítani, ez ma a legtöbb magyar város fejlesztési politikája. [...] Ha Szegeden valami terv vetődik föl, alig merünk róla tudósítást közölni, mert bizonyos, hogy más városok rögtön belekapaszkodnak, $s$ ha már nem is sikerül nekik, arra törekszenek, hogy a szegedi tervet meghiúsítsák. Nem más ez, mint az árdrágítás és tehetetlen konkurrálás nagyított és bővített kiadása, amely anynyi szép intézmény megvalósítását akadályozta már meg nálunk is, máshol is. Sem élni, sem meghalni nem engedik egymást a magyar városok s hogy ma még sok tekintetben oly nagy a hátramaradottság, abban nem kis része van ennek az egészségtelen, kapkodó, cél és terv nélküli versengésnek." ${ }^{28}$

${ }^{28}$ „Tolongás az új műegyetemért”, Szeged és Vidéke 32 (1918), 1918. február 9. A sajtókampány talán annak tudható be, hogy amikor Szeged a harmadik tudományegyetem elnyeréséért lobbizott, Temesvár a támogatója volt (végül 1912-ben Debrecenben nyílhatott meg az intézmény). Szeged és Temesvár között akkor olyan megállapodás született, amely szerint Szeged a kölcsönösség alapján támogatni fogja Temesvár érdekeit a műegyetem elnyerése kapcsán. Minderről dr. Somogyi Szilveszter szegedi polgármester nyilatkozott a városi lapban. Ezt azért is fontos volt hangsúlyozni, mert az 1917. novemberi minisztériumi értekezletről olyan sajtóértesülések keringtek a Tisza-parti városban, amely szerint az összejövetelen a miniszter kijelentette, hogy a műegyetem ügyében végleges nyilatkozatot nem tehet, a háború alatt szó sem lehet a végleges létesítéséről, de amint lehet, bizottságot küld Temesvárra. „Mi sem természetesebb, mint hogy ezeket a hireket elolvasták Szegeden is, ahol széles körben bizonyos nyugtalanságot keltett, amely bizonyosan még az egyetemért folytatott harcok idejéböl maradt fönn. Hangok 
Ezzel egyben a Temesvár kontra Selmecbánya kérdés is végleg eldőlt. A bányaváros, amely az első világháborút megelőzően maga is pályázott a müegyetemi rangra, ebben az időben többféle elképzelés mentén igyekezett kapcsolódni a műegyetemi reformjavaslatokhoz. Az egyenjogúsítás felvetésétől és a teljes főiskolává tételtől elindulva ${ }^{29}$ a háború alatti években született selmeci elképzelésekben a meglévő karok mellé újabbak, közte az elektrotechnikai [!] létrehozása szerepelt. 1918 tavaszán olyan javaslatot készítettek, amelyben a fóiskola a bányászati ágazatoknak önálló fakultásként a Mủegyetemhez, az erdészetinek pedig szintén a Müegyetemhez vagy a pozsonyi Erzsébet Tudományegyetemhez történő csatolását tartalmazta. A Mủegyetem által kiküldött bizottság az ágazatok idecsatolását célszerűtlennek és nem megvalósíthatónak minősítette. ${ }^{30}$ Az ezt követő újabb elképzelés szerint Kassához csatlakozott volna a selmeci fóiskola, azonban a müegyetemi bizottság továbbra is ragaszkodott a teljes műegyetem megteremtéséhez (vagyis nem lett volna elegendő a bányászati, kohászati, erdészeti mellé az építészeti kar létrehozása). ${ }^{31} \mathrm{~A}$ második mủegyetem létrehozásával párhuzamosan ugyanis 1917 őszén a harmadik magyar műegyetem terve is felmerült, amelynek székhelyéül a szakmai közvélemény Kassát jelölte meg (emellett Miskolc neve is felmerült). ${ }^{32} \mathrm{~A}$ város 1918 januárjában nyújtotta be emlékiratát, a Műegyetem által kiküldött bizottság pedig 1918 nyarára készítette el jelentését. ${ }^{33} \mathrm{~A}$ város bányászati, kohászati, illetve építészeti hangsúllyal rendelkező felsőoktatási intézmény alapítására volt alkalmas, valamint a szakemberek ebben az esetben is hangsúlyozták a magyar gazdaságot erősítő hatását. ${ }^{34} \mathrm{~A}$ Kassa melletti érvek között szerepelt az is, hogy Észak-Magyarország legfontosabb történelmi városa, szellemi központja, "megviviatatlan bástyatorony” (akárcsak Temesvár a Délvidéken), illetve az 1660-ban alapított egyetemi elözmény is, amely 1777-ig működött. Fontos szempont volt, hogy a Kassához közeli és távolabbi 20 megyéből a háborút megelőző utolsó három tanévben a műegyetemi hallgatók

hallatszottak, amelyek szerint Szegednek is akcióba kellene lépni a müegyetem megszerzéséért. A hatóságot tehetetlenséggel vádolták, hogy ismét Szeged erös riválisát, Temesvárt hagyja boldogulni és még csak lépést sem tesz az egyetemi intézmény megszerzése érdekében, holott arra egyetlen magyar városnak sincs annyi joga, mint éppen Szegednek.” A hír nyomán feltámadó szenvedély egyre intenzívebb méreteket öltött, a város polgármestere ezért igyekezett a kedélyeket csillapítani.

29 Selmecbánya a temesvári kezdeményező lépéseket követően szintén felirattal fordult a kultusztárcához (ezt a Müegyetem is megkapta), amelynek tárgya a föiskola egyenjogúsítása volt. BMEL 3/c. 45. d. RH 44. t., 1117/1913. sz.

30 BMEL 3/a. 5. d., az Egyetemi Tanács 1918. április 19-i ülésének 145. napirendi pontja.

31 BMEL 3/b. 7. k., a Rektori Tanács 1917. október 2-i ülése, valamint BMEL 3/c. 50. d., 1341/1917. sz. rektori hivatali irat.

32 A Magyar Mérnök és Építész Egylet 1917 novemberében tartott a kérdésben tanácskozást.

33 BMEL 3/c. 51. d. 34. t. rektori hivatali iratok.

34 „A modern közgazdaság nem nélkülözheti a technikai tudományos munkát, még östermelést sem lehet a mai világversengésben tudományos alap nélkül sikerrel folytatni!" A kassai bizottsági emlékirat egyébként Japán példáját elemzi a fejlődéshez szükséges lépések felvázolása kapcsán. BMEL 3/c. 51. d. 34. t. 495. és 1273/1918. sz. rektori hivatali iratok. 
20\%-a (több mint 500 fó) érkezett, így a kassai műegyetem létrehozása szintén automatikusan enyhítette volna a budapesti zsúfoltságot. Másrészt a kínálat várhatóan ebben az esetben is generálta volna a keresletet, azaz megnövekedett volna a technikai pályára menni szándékozó fiatalok száma. Köztük a szlovák anyanyelvű ifjaké is, akik a brünni vagy prágai intézmény helyett Kassát választhatták volna (kb. 20 „magyarhonos tót" fó járt Budapestre, míg a cseh intézményekbe háromszor annyian). Azonban itt az előkészületek nem jutottak olyan messzire, mint Temesvár esetében.

Bár a műegyetemi bizottság 1919 szeptemberére kitűzte a temesvári egyetem megnyitását, ez a történelmi eseményekből kifolyólag csak 1920 őszén történt meg, ám akkor már román politechnikumként. ${ }^{35} \mathrm{~A}$ megváltozott történelmi-politikai helyzetben Kassán is csak 1937-ben nyílt meg az immár szlovák műegyetem (majd 1952-ben újranyitották). További érdekesség, hogy a bécsi döntéseket követően 1941 szeptemberében Nagyvárad törvényhatósági bizottsága felterjesztéssel fordult a kultuszminiszterhez, amelyben régi kívánságára tekintettel kérte a második magyar müegyetem ott történő létrehozását. Bár maga a felterjesztés is rámutatott arra, hogy két tudományegyetemi város, Debrecen és Kolozsvár között fekszik, így aligha lehet remény arra, hogy egyetemet kapjon, ám a várost ipari és kereskedelmi jellege miatt mégis alkalmasnak vélték az ország második műszaki egyetemének elhelyezésére.

Az új magyar mủegyetemek végül csak a második világháborút követően alakultak meg. 1948-ban hívtak össze bizottságot a műegyetemi reform kidolgozására, amely megállapította a Mủegyetem és a frissen létrehozott, munka melletti tanulmányokat biztosító Állami Műszaki Főiskola újjászervezésére vonatkozó irányelveket. A magyar iparnak a három- és az ötéves tervvel kapcsolatos becslések szerint évente mintegy 2000 mérnökre volt szüksége, amelyből a BME és az ÁMF mindössze évi 1000 végzett mérnököt tudott a gyáripar rendelkezésére bocsátani. Ezt a hiányt a műszaki felsőoktatás nagymértékủ szakosításával és a tanulmányi idő csökkentésével is igyekeztek mérsékelni, a további intézkedések pedig szovjet mintájú szakegyetemek létrehozását eredményezték (1949-ben jött létre a Veszprémi Vegyipari Egyetem, 1952-ben pedig a miskolci Nehézipari Műszaki Egyetem).

35 Szögi László kutatásaiból tudható, hogy a kultusztárca a temesvári egyetemalapítás ügyét 1918. november közepén ad acta tette. Vö. SzöGI, „A temesvári...”, 118. 